\title{
Psychological Determinants of Household Financial Sustainability: The Perspective of Employees in Manufacturing Sector of Malaysia
}

\author{
Syed Inaam Ullah Shah ${ }^{*} \quad$ Amina Bashir $^{\dagger} \quad$ Muhammad Ishaq Biland ${ }^{\ddagger}$
}

\begin{abstract}
Financial sustainability is a hot topic these days. Previous studies have explored the effects of socioeconomic characteristics on financial sustainability. However, this stream of research has paid little attention to psychological factors that may be related to financial sustainability of household. Therefore, the aim of the present study is to fill the research gap by examining the effects of financial attitudes, financial behavior and financial self-efficacy on financial sustainability. To meet the study objectives, data were collected from 284 employees working in Malaysian manufacturing sector. The collected data was then analyzed using the PLS-SEM approach. The results of this study show that financial attitudes, financial behavior and financial self-efficacy have a significant impact on the financial sustainability of employees affiliated with manufacturing sector of Malaysia.
\end{abstract}

Keywords: Financial attitudes, financial behaviors, financial self-efficacy, financial sustainability, household, psychological factors.

\section{Introduction}

Financial sustainability (FS) is a subject that scientists and researchers from a variety of fields are increasingly interested in. It has been attempted to clarify a view of the FS and to discern what factors lead to FS or wellness. FS is described by Navarro-Galera, Rodríguez-Bolívar, Alcaide-Muñoz, and López-Subires (2016) as satisfaction with one's current financial situation and debt level. According to De Goede (2010), financial security is a feeling of being financially secure, happy, and worry-free, and is based on an emotional assessment of a person's financial situation. However, Jordão et al. (2017) define FS as an individual's overall satisfaction with his or her financial situation. The combination of two words, finance and well-being, eliminates one of the most significant impediments to people focusing on their finances: the propensity to think of monetary matters as separate from or detached from other aspects of life. FS has a huge impact on one's level of personal satisfaction. FS is important from the viewpoint of an individual, and studies have shown that it has a solid and positive relationship with a person's overall well-being. According to Jordão et al. (2017), a prudent spending pattern and a healthy savings account balance are important factors in determining personal well-being. Furthermore,

\footnotetext{
*Universiti Utara Malaysia, Malaysia. Email: inaamgilani@gmail.com

${ }^{\dagger}$ M. Phil Scholar, Gift University, Pakistan. E-mail: 191610014@gift.edu.pk

$\ddagger$ Ph.D Scholar, The University of Swabi, Pakistan. E-mail: ishaq.biland@gmail.com
} 
they have an effect on workers' mental and physical well-being, as well as improving workplace performance by enhancing the responsibilities of their employment.

A disparity in FS among employees, on the other hand, could have a negative impact on the productivity of the organization. Employees who are financially ill are often depressed and distracted, which has a negative impact on absenteeism, productivity, retirement, and medical costs. As a result, employee well-being is a vital aspect that companies strive to deliver in order to ensure that their employees remain satisfied and motivated at work. In the end, a happy workforce not only means a productive workforce, but also a productive work environment. Furthermore, employees of exchanging firms are likely to lose revenue and non-financial benefits of working for the firm, making bankruptcy more expensive for employees. Bankruptcy is a legal procedure that allows people who are unable to repay their debts to seek relief from any or all of their obligations. In most jurisdictions, bankruptcy is compelled by a court order, which is usually initiated by the individual who is in debt. Organizations that care for their employees' well-being are less likely to go bankrupt, compared to those that don't. Since bankruptcy occurs when a corporation is unable to meet its debt obligations, reducing the company's influence is an undeniable method of reducing the risk of financial distress. Furthermore, an abnormal level of employee well-being is linked to a lower debt-to-assets ratio (Mao \& Weathers, 2019).

In the last five years, a few Malaysians between the ages of 18 and 44 have been declared bankrupt. According to data from the Insolvency Department, the highest number of adolescent bankruptcy cases were registered in 2014, with a total of 13,098 cases, followed by 13,036 cases in 2013 (Sabri, Wijekoon, \& Rahim, 2020). This problem can be complicated by identifying potential bankrupts and the factors that go along with them. Few people go bankrupt due to a lack of financial responsibility or failure to manage their finances. The majority of bankruptcies are caused by financial distress rather than reckless spending, and many are low-income individuals who are unable to cope with unexpected significant costs, such as work loss or medical expenses. Debt restructuring options, such as debt management plans, debt consolidation loans, and debt arbitration, may be used by employers as a way to avoid bankruptcy. Various variables have all the earmarks of being consistently linked with FS, according to academics. Demographic and socioeconomic characteristics, such as age, gender, ethnicity, education, marital status, and income, are the most generally known criteria. Although certain demographic factors have been linked to FS, other variables such as financial attitude, and financial self-efficacy (Sabri et al., 2020) may also have an effect. As a result, the primary goal of this study is to investigate the factors that influence FS among employees working in manufacturing sector of Malaysia.

\section{Financial Sustainability}

Financial sustainability is described as a local government's ability to meet its obligations to provide services to the public on a continuous basis while maintaining the local budget's financial stability in the short and long term. According to Gorina (2013), a crucial 
prerequisite for ensuring the financial viability of local budgets is the willingness of local councils to ensure the implementation of the expenditure side of budgets from their own revenues. Financial sustainability, according to Lysiak, Kachula, Hrabchuk, Filipova, and Kushnir (2020), represents not only the capacity to produce adequate revenue, but also the manner in which income and expenditure obligations are met. To put it another way, financial sustainability refers to the budget's balance as well as the chance of it being breached.

Financial sustainability, according to Chapman (2008), is the willingness of local governments to fulfill their financial commitments on a stable basis for the long term (cyclical, structural and intergovernmental). Among the various types of responsibilities mentioned, cyclical responsibilities are found at all levels of government. Demographic developments, general population and business mobility, technological changes in the consumption of goods and services, and the expansion of sources of revenue for the municipal budget all influence structural liabilities. Local governments' ability to control some of these mechanisms has the potential to make local budgets more manageable. Interstate commitments occur as a result of international technical assistance or loans from international financial institutions, and they have an effect on local financial resources.

Barbera, Jones, Korac, Saliterer, and Steccolini (2017) distinguishes between financial sustainability of local budgets that is passive and active. Passive sustainability, according to them, is the ability to adapt to crises, i.e., the ability to return to a previous state, while active sustainability is the ability to predict challenges and cope with them through socio-economic growth and the creation of new opportunities. Active (using instruments to promote the socio-economic growth of territories, creating favorable conditions and incentives for development) and passive (using automatic stabilizers, which, at best, would guarantee a return to the pre-crisis financial state of the local budget) budget sustainability refers to a specific form of budget policy (Lysiak et al., 2020). Lucianelli, Citro, Santis, Tranfaglia, and Mazzillo (2018) consider the following main elements when determining financial sustainability at the local/regional level in a crisis: quality of public services, cost efficiency, optimum debt commitments, and intergenerational integration, keeping in mind that achieving sustainability does not jeopardize future generations' ability to meet their needs.

The popularity of FS is growing in a number of countries. The focus is primarily on the factors that lead to increased community well-being and the policies that will help to achieve it. A significant number of studies have focused on the general FS of residents, rather than the negative consequences of well-being, such as deficiency, financial burden, or payment difficulties (Townsend, 2014). Despite the fact that various studies have attempted to calculate the dimension of general FS in citizens from various countries, the vast majority of them depend on personal interventions, applying compositions to general health and well-being. There is, however, no standard definition or strategy for estimation, and the content of questionnaires has been defined normatively.

FS connects concepts from the realms of individual finance and the broader realm of individual well-being. Both criteria have evolved at the same time and share a number of features, including economics, psychology, and health (Marston, Banks, \& Zhang, 2018). The CFPB (2015) has started a qualitative investigation into the potential links between FS 
and financial expertise, literacy, financial capacity, and personality traits. They've spoken about each of these three zones with customers and financial advisors to see how they perceive their ability to highlight FS and their relative importance. When it comes to initial performance evaluations, the ones listed in the discussion have been grouped into four categories: efficient repetitive monetary management; efficient financial investigation and information gathering; financial design and target setting; and following through on financial conclusions. The indirect influence was exposed as intelligence, abilities, and personality traits when it came to the effect on behaviors. Aside from a person's physical features, the social and economic climate was also considered, and played a significant role in determining FS (CFPB, 2015). In many countries, improving personal well-being has become a critical strategy requirement. These criteria compelled researchers to place a high priority on comprehending it, estimating it, and researching ways to better improve the characteristics that lead to happiness. Various variables have all the earmarks of being consistently linked with FS, according to academics. Demographic and socioeconomic characteristics, such as age, gender, ethnicity, education, marital status, and income, are the most generally known criteria (Sahi, 2013). Although some demographic factors have been linked to FS, other variables such as financial attitude, financial behavior, and FSE (Sabri et al., 2020) may also have an effect.

\section{Financial Attitude and FS}

Financial attitude is a form of behavior in which a person's evaluation results in exclusive benefits of, or a feature, and the symbolic value of money may influence purchasing behavior (Widaningsih \& Mustikasari, 2019). Financial attitude, according to Siswanti and Halida (2020), is a person's ability to make financial decisions. Money is described by a person as a tool that has the ability to influence money management activities. Indeed, one's financial attitudes can influence their shopping and saving habits, as well as the achievement of specific life objectives. Individuals achieve life fulfillment when they set fruitful life goals, and attempted to support the connection between FS and life satisfaction. Furthermore, Rimple et al. (2020) discovered a positive relationship between financial attitude and university students in their research. Various studies in the field of economic psychology, particularly in recent years, have looked at people's attitudes and beliefs about money. According to cross-sectional studies, there is a positive relationship between financial attitude and financial literacy (Trzcińska, Sekścińska, \& Maison, 2018). As a result, we can formulate a hypothesis in the following manner. ity.

H1: There is a significant association of workers' financial attitudes and financial sustainabil-

\section{Financial Behaviour and FS}

Financial behavior is a concept that refers to a collection of routine techniques or traditional working methods that are used to complete accounting, financial detailing, budget- 
ing, and other tasks related to business finances. Better financial behavior of financially distressed customers was thought to play an important role in improving their health and FS dimensions by reducing financial distress (Brüggen, Hogreve, Holmlund, Kabadayi, \& Löfgren, 2017). One of the functional factors of FS is financial activity (Xiao, Tang, \& Shim, 2009). Developing good financial habits while in school increases a person's chances of living a better life later on (Hancock, Jorgensen, \& Swanson, 2013). As a result, the hypothesis will be formulated as follows: ability.

H2: There is a significant association of workers' financial behaviours and financial sustain-

\section{Financial Self-Efficacy and FS}

Customers with high perceived financial FSE are confident in their ability to gather data in order to make informed financial decisions, confident in their ability to make wise decisions, and confident in their financial self-control. The FSE causes financial anxiety to be avoided, as well as the harmful financial behaviors that go along with it (Netemeyer, Warmath, Fernandes, \& Lynch Jr, 2018). The FSE can assist customers in responding to difficult current circumstances by motivating them to solve problems (Chang, Ferris, Johnson, Rosen, \& Tan, 2012). Furthermore, Hancock et al. (2013) discovered that financial effectiveness is related to financial happiness and FS in an indirect positive way. Along these lines, a positive association between FSE and the FS has been discovered. Asebedo and Payne (2019) used an econometric model to expose the relationship between financial FSE and women's personal FS, and financial FSE thrives to explain its role in personal financial conduct. Furthermore, previous research has found a connection between financial effectiveness and FS (Brüggen et al., 2017). As a result, the following hypothesis was created. ability.

H3: There is a significant association of workers' financial self-efficacy and financial sustain-

\section{Methodology}

The present study adopted a quantitative approach and a cross-sectional design. The data was collected through self-administered questionnaires. Using random sampling, a total of 284 employees working in manufacturing sector in Malaysia was considered as study sample. The 6-itmes scale developed by Furnham (1984) was used to measure the construct of financial attitudes. A 5-item scale adapted from the study of Gautam and Matta (2016) to analyze the financial behavior. The construct of financial self-efficacy was measured by 5-items scale (Lown, 2011). Finally, financial sustainability was measured by 5-items scale (Anderloni, Bacchiocchi, \& Vandone, 2012). All the constructs were measured at 5 -point Likert scale ranging from $1=$ strongly disagree to $5=$ strongly agree. The 
collected data was then analyzed by PLS-SEM approach using SmartPLS 3 software.

Figure 1

Conceptual Framework

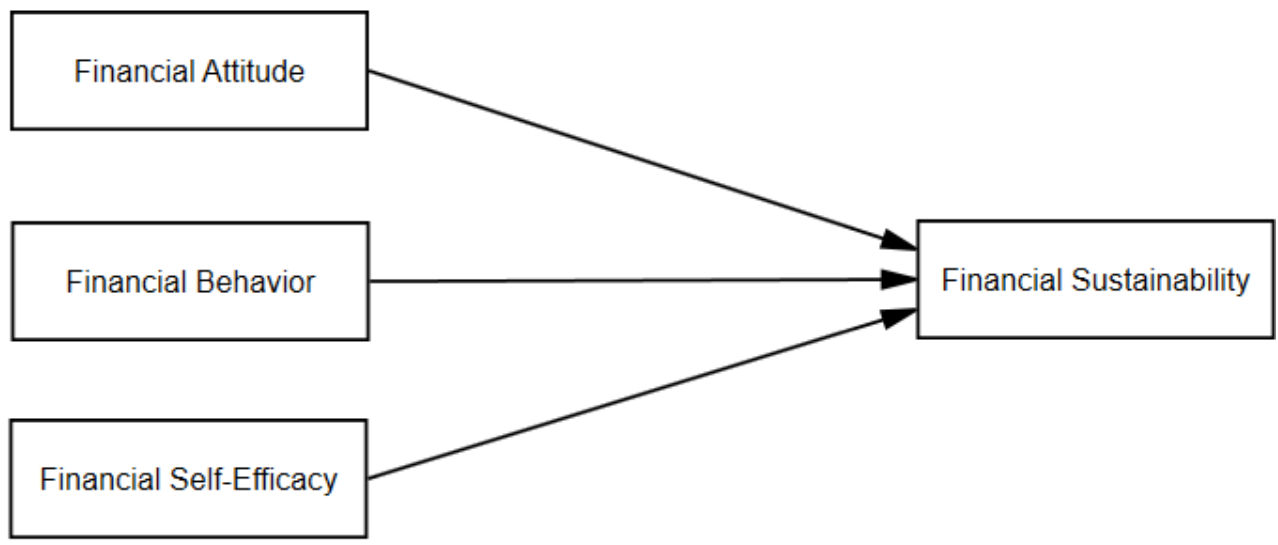

\section{Results}

The investigator conducted the CFA test in this section of the paper, which was used to assess the measurement model. This method has been used to verify the internal consistency of each latent variable, which needs a minimum rational value of 0.6 in terms of composite reliability and Cronbach Alpha. Since the lowest value of Cronbach's alpha is calculated to be 0.702 , and the composite reliability value is 0.815 , the results from Table 1 show that all of the latent variables in this study are reliable. Furthermore, another important aspect of the CFA research is the calculation of external loading, which was also done by the investigator. For outer loading, 0.5 is the threshold value.

As a result, all outer load values are greater than 0.5 , with the lowest value being 0.653, as shown in Figure 1 and Table 1. Furthermore, the value of outer loadings with bootstrapping was identified, which was found to be important. On the other hand, the interaction and relation of latent structures was assessed in terms of convergent validity, and the AVE threshold was set at 0.5 (Gikama, 2019; Shah \& Abd Rahim, 2019). Table 1 shows that all variables have convergent validity since the minimum AVE was 0.526.

In order to determine convergent validity and reliability, it is also necessary to recognize the distinctness of variables (Hair, Hult, Ringle, Sarstedt, \& Thiele, 2017). The Forner and Larcker criterion, as well as the HTMT ratio, were then used to assess the distinct significance of two variables, with 0.85 being the highest acceptable value for HTMT (Kock, 2015). The square root of each variable's AVE must be greater than its correlation with other variables, according to the former and Larker criterion. Table 2 and Table 3 demonstrate the discriminant validity of the study's variables. 
Table 1

\begin{tabular}{|c|c|c|c|c|c|}
\hline Construct & Items & Loadings & Cronbach's Alpha & CR & AVE \\
\hline \multirow[t]{4}{*}{ Financial Attitude } & FA1 & 0.780 & 0.748 & 0.840 & 0.568 \\
\hline & FA2 & 0.725 & & & \\
\hline & FA3 & 0.733 & & & \\
\hline & FA4 & 0.774 & & & \\
\hline \multirow[t]{4}{*}{ Financial Behaviour } & FB1 & 0.669 & 0.706 & 0.818 & 0.530 \\
\hline & FB2 & 0.788 & & & \\
\hline & FB3 & 0.711 & & & \\
\hline & FB4 & 0.737 & & & \\
\hline \multirow{3}{*}{ Financial Self-Efficacy } & FS3 & 0.812 & 0.702 & 0.815 & 0.526 \\
\hline & FS4 & 0.792 & & & \\
\hline & FS5 & 0.833 & & & \\
\hline \multirow[t]{4}{*}{ Financial Sustainability } & FSE1 & 0.653 & 0.744 & 0.853 & 0.660 \\
\hline & FSE2 & 0.658 & & & \\
\hline & FSE3 & 0.820 & & & \\
\hline & FSE5 & 0.757 & & & \\
\hline
\end{tabular}

Note: Removed items FA5,F6,FB5,FB6,FS1,FS2,FSE4

Table 2

Fornell and Larcker Criterion for Discriminant Validity

\begin{tabular}{lcccc}
\hline & $\begin{array}{c}\text { Financial } \\
\text { Attitude }\end{array}$ & $\begin{array}{c}\text { Financial } \\
\text { Behaviour }\end{array}$ & $\begin{array}{c}\text { Financial } \\
\text { Self-Efficacy }\end{array}$ & $\begin{array}{c}\text { Financial } \\
\text { Sustainability }\end{array}$ \\
\hline Financial Attitude & 0.753 & & & \\
Financial Behaviour & 0.448 & 0.728 & & \\
Financial Self-Efficacy & 0.574 & 0.494 & 0.725 & \\
Financial Sustainability & 0.497 & 0.525 & 0.553 & 0.812 \\
\hline
\end{tabular}

Table 3

Heterotrait-Monotrait Criterion for Discriminant Validity

\begin{tabular}{lcccc}
\hline & $\begin{array}{c}\text { Financial } \\
\text { Attitude }\end{array}$ & $\begin{array}{c}\text { Financial } \\
\text { Behaviour }\end{array}$ & $\begin{array}{c}\text { Financial } \\
\text { Self-Efficacy }\end{array}$ & $\begin{array}{c}\text { Financial } \\
\text { Sustainability }\end{array}$ \\
\hline Financial Attitude & & & & \\
Financial Behaviour & 0.594 & & & \\
Financial Self-Efficacy & 0.789 & 0.704 & & \\
Financial Sustainability & 0.650 & 0.697 & 0.743 & \\
\hline
\end{tabular}

\section{Hypothesis Testing}

The researcher evaluated the significance of hypothesized pathways in the Model performance after checking the estimation model, which aids in determining the reliability and relevance of variables in latent constructs. As a result, the relevance and effect of the findings were assessed using bootstrapping, and the results were presented in Table 4 and Figure 2. According to Hair et al. (2017), bootstrapping is a form of subsampling and resampling that can be used to determine the meaning. The findings contained in Table 4 show that the impact of financial attitude $(B=0.157 ; p$-value $=0.003<0.05)$, financial behaviour $(B=0.184$; $p$-value $=0.001<0.05)$, and financial self-efficacy $(B=0.238$; $p$-value $=$ $0.000<0.05$ ) on the employee's financial sustainability in Malaysian production industry is established. 
Table 4

Hypotheses Results

\begin{tabular}{lccccccc}
\hline Hypothesis & Beta & S.E & T Value & P Value & CIBCa Low & CIBCa High & Decision \\
\hline Financial Attitude - > FS & 0.196 & 0.056 & 3.484 & 0.001 & 0.095 & 0.303 & Supported \\
Financial Behaviour - > FS & 0.291 & 0.062 & 4.708 & 0.000 & 0.162 & 0.402 & Supported \\
Financial Self-Efficacy - > FS & 0.297 & 0.061 & 4.880 & 0.000 & 0.177 & 0.412 & Supported \\
\hline Note: FS = Financial Sustainability & & & & & & \\
* Significance level $<$ 0.05 & & & & & & &
\end{tabular}

\section{Discussion and Conclusion}

The PLS-SEM approach was used to investigate the contributory factors of FS among Malaysian employees in this research. The current study's ramifications include a number of important insights. To begin, the findings suggested that workers must demonstrate necessary financial behaviour, such as saving, cash management, and credit management, among other things, in order to become financially stable. When workers have good financial behaviours, their FS is expressed as high. That is consistent with previous research (Sabri et al., 2020), and it was discovered that positive financial behaviours have a positive impact on FS. Employees who have good financial behaviors such as investing, budgeting, not using risky credit cards, and being less prone to compulsive buying have dramatically increased the FS, according to the study. It means that significant financial behaviours are important since they assess the potential changes in FS (Gerrans, Speelman, \& Campitelli, 2014). Similarly, Hancock et al. (2013) found that proper financial methods in money management, credit card management, and saving were positively related to the FS. As a result, financial education initiatives would be recommended in order to encourage good financial behaviour and thereby increase employees' FS directly.

Second, people with a good financial attitude are more likely to be careful with their spending by budgeting and preparing for their future financial needs. Furthermore, it clearly demonstrates the impact of money attitudes on the relationship between subjective and objective wealth indicators among Malaysian employees. Third, the findings back up the theory that the general FSE and FS have a positive relationship. Previous research backs up the conclusion (Sabri et al., 2020). As pressure levels increased, people with lower levels of FSE showed a greater decrease in mental health than those with higher levels of FSE. As a result, general FSE plays a significant role in FS. According to Henning and Jordaan (2016), work management reduces the negative effects of difficulties on anxieties in people with high FSE, and this has pressure-lowering effects in people with low FSE. As a result, the employee FSE levels is critical for both increasing workplace efficiency and enhancing employee well-being.

All things considered, an employer-sponsored work atmosphere that includes financial counseling and education may be a good investment in the future. Financial awareness improvement initiatives, such as cluster seminars on acceptable financial behaviour or individual financial counsellor-employee services, can be useful in assisting employees. Hancock et al. (2013) hypothesized that good financial training delivered in a classroom setting will be both beneficial and accessible to a larger community of employees. It may be persuasive in motivating Malaysian workers to participate in FS. Reduced financial 
stress can help workers be more concentrated at work, which is beneficial to businesses.

To conclude, this research adds to our understanding of the impact of financial behaviour, financial attitudes, and FSE on employees' FS. It appears that it is important to distinguish between the instrumental and affective dimensions of financial behaviour, FSE, and financial attitudes, as their effect on the relationship between subjective and objective wealth measures differs. To strengthen our understanding of the current research, more future studies will be needed to replicate the results described in this paper in different samples and cultures, and with different measures of FS and financial behaviour, FSE, and financial attitudes. 


\section{References}

Anderloni, L., Bacchiocchi, E., \& Vandone, D. (2012). Household financial vulnerability: An empirical analysis. Research in Economics, 66(3), 284-296.

Asebedo, S., \& Payne, P. (2019). Market volatility and financial satisfaction: The role of financial self-efficacy. Journal of Behavioral Finance, 20(1), 42-52.

Barbera, C., Jones, M., Korac, S., Saliterer, I., \& Steccolini, I. (2017). Governmental financial resilience under austerity in Austria, England and Italy: How do local governments cope with financial shocks? Public Administration, 95(3), 670-697.

Brüggen, E. C., Hogreve, J., Holmlund, M., Kabadayi, S., \& Löfgren, M. (2017). Financial well-being: A conceptualization and research agenda. Journal of Business Research, 79, 228-237.

Chang, C.-H., Ferris, D. L., Johnson, R. E., Rosen, C. C., \& Tan, J. A. (2012). Core selfevaluations: A review and evaluation of the literature. Journal of Management, 38(1), 81-128.

Chapman, J. I. (2008). State and local fiscal sustainability: The challenges. Public Administration Review, 68, S115-S131.

De Goede, M. (2010). Financial security. The Routledge Handbook of New Security Studies. London: Routledge, 100-109.

Furnham, A. (1984). Many sides of the coin: The psychology of money usage. Personality and Individual Differences, 5(5), 501-509.

Gautam, S., \& Matta, M. (2016). Socio-demographic determinants of financial behaviour of individual investors in India. Journal of IMS Group, 13(1), 38-49.

Gerrans, P., Speelman, C., \& Campitelli, G. (2014). The relationship between personal financial wellness and financial wellbeing: A structural equation modelling approach. Journal of Family and Economic Issues, 35(2), 145-160.

Gikama, G. (2019). Does gearing influence on corporate performance? Evidence from Kenya. International Journal of Management and Sustainability, 8(1), 1-9.

Gorina, E. (2013). Fiscal sustainability of local governments: Effects of government structure, revenue diversity, and local economic base (Unpublished doctoral dissertation). Arizona State University.

Hair, J. F., Hult, G. T. M., Ringle, C. M., Sarstedt, M., \& Thiele, K. O. (2017). Mirror, mirror on the wall: a comparative evaluation of composite-based structural equation modeling methods. Journal of the Academy of Marketing Science, 45(5), 616-632.

Hancock, A. M., Jorgensen, B. L., \& Swanson, M. S. (2013). College students and credit card use: The role of parents, work experience, financial knowledge, and credit card attitudes. Journal of Family and Economic Issues, 34(4), 369-381.

Jordão, R. V. D., et al. (2017). Performance measurement, intellectual capital and financial sustainability. Journal of Intellectual Capital.

Kock, N. (2015). Common method bias in PLS-SEM: A full collinearity assessment approach. International Journal of e-Collaboration, 11(4), 1-10.

Lucianelli, G., Citro, F., Santis, S., Tranfaglia, A., \& Mazzillo, A. (2018). How to improve the financial conditions of local governments in a period of crisis: An explanatory case study. International Journal of Business and Management, 13(1), 53-69. 
Lysiak, L., Kachula, S., Hrabchuk, O., Filipova, M., \& Kushnir, A. (2020). Assessment of financial sustainability of the local budgets: Case of Ukraine. Public and Municipal Finance, 9(1), 48-59.

Mao, C. X., \& Weathers, J. (2019). Employee treatment and firm innovation. Journal of Business Finance \& Accounting, 46(7-8), 977-1002.

Marston, G., Banks, M., \& Zhang, J. (2018). The role of human emotion in decisions about credit: Policy and practice considerations. Critical Policy Studies, 12(4), 428-447.

Navarro-Galera, A., Rodríguez-Bolívar, M. P., Alcaide-Muñoz, L., \& López-Subires, M. D. (2016). Measuring the financial sustainability and its influential factors in local governments. Applied Economics, 48(41), 3961-3975.

Netemeyer, R. G., Warmath, D., Fernandes, D., \& Lynch Jr, J. G. (2018). How am i doing? perceived financial well-being, its potential antecedents, and its relation to overall well-being. Journal of Consumer Research, 45(1), 68-89.

Rimple, M., et al. (2020). A gendered study of attitude towards money in Delhi NCR. Studies in Business and Economics, 15(1), 115-126.

Sabri, M., Wijekoon, R., \& Rahim, H. (2020). The influence of money attitude, financial practices, self-efficacy and emotion coping on employees' financial well-being. Management Science Letters, 10(4), 889-900.

Shah, S. I. U., \& Abd Rahim, N. (2019). Effect of ethical climate on corporate financial performance in Pakistan: An application of confirmatory tetrad analysis (CTA-PLS) approach. Journal of Studies in Social Sciences and Humanities, 5(2), 53-67.

Siswanti, I., \& Halida, A. M. (2020). Financial knowledge, financial attitude, and financial management behavior: Self-control as mediating. The International Journal of Accounting and Business Society, 28(1), 105-132.

Townsend, P. (2014). International analysis poverty. UK: Routledge.

Trzcińska, A., Sekścińska, K., \& Maison, D. (2018). The role of self-control and regulatory foci in money-saving behaviours among children. Current Psychology, 1-11.

Widaningsih, S., \& Mustikasari, A. (2019). The effect of fashion orientation, money attitude, self esteem, and conformity on compulsive buying: A study on youth customer in bandung. In 1st International Conference on Economics, Business, Entrepreneurship, and Finance (ICEBEF 2018) (pp. 639-642).

Xiao, J. J., Tang, C., \& Shim, S. (2009). Acting for happiness: Financial behavior and life satisfaction of college students. Social Indicators Research, 92(1), 53-68. 